\title{
Criminal law in the European Union : inaugural lecture, Maastricht University, 29 april 2004
}

Citation for published version (APA):

Klip, A. H. (2004). Criminal law in the European Union : inaugural lecture, Maastricht University, 29 april 2004. Maastricht University. https://doi.org/10.26481/spe.20040429ka

Document status and date:

Published: 29/04/2004

DOI:

$10.26481 /$ spe.20040429ka

Document Version:

Publisher's PDF, also known as Version of record

\section{Please check the document version of this publication:}

- A submitted manuscript is the version of the article upon submission and before peer-review. There can be important differences between the submitted version and the official published version of record.

People interested in the research are advised to contact the author for the final version of the publication, or visit the DOI to the publisher's website.

- The final author version and the galley proof are versions of the publication after peer review.

- The final published version features the final layout of the paper including the volume, issue and page numbers.

Link to publication

\footnotetext{
General rights rights.

- You may freely distribute the URL identifying the publication in the public portal. please follow below link for the End User Agreement:

www.umlib.nl/taverne-license

Take down policy

If you believe that this document breaches copyright please contact us at:

repository@maastrichtuniversity.nl

providing details and we will investigate your claim.
}

Copyright and moral rights for the publications made accessible in the public portal are retained by the authors and/or other copyright owners and it is a condition of accessing publications that users recognise and abide by the legal requirements associated with these

- Users may download and print one copy of any publication from the public portal for the purpose of private study or research.

- You may not further distribute the material or use it for any profit-making activity or commercial gain

If the publication is distributed under the terms of Article $25 \mathrm{fa}$ of the Dutch Copyright Act, indicated by the "Taverne" license above, 


\section{INAUGURAL LECTURE}

MAASTRICHT UNIVERSITY, 29 APRIL 2004

Prof. mr. André Klip

\section{Introduction}

On February $7^{\text {th }} 1992$, the Treaty on European Union was concluded in this city. With this treaty a development started that makes it impossible any longer to look at criminal justice as purely national. Whether or not consciously, steps were taken that could lead to a common European criminal justice system. The essence of my argument today deals with the meaning of this fundamental and structural change in criminal justice from national to European level for criminal legislation, criminal policy and research in criminal law. ${ }^{2}$

\section{The position of criminal law in our society}

At the present juncture, criminal law enjoys a lot of attention from the media, government and politics. From this point of view, criminal law is doing very well. Themes related to criminal law cannot be missed in the news bulletins. Almost every citizen has an opinion on what and who should be punished, how that should be carried out, and how severe the penalty should be. I welcome that my field of law takes such a central position in society. But all this attention has its drawbacks. The expectations on what can be reached with criminal law are very high, ${ }^{3}$ too high in my opinion. In many cases criminal law, at least the image of it, has become primum remedium: one of the first means to be used to fight unwanted behaviour. This development is not strictly Dutch and it has taken place in other countries and certainly in the European Union as well. ${ }^{4}$ On top of that, if there is one protagonist of the idea of primum remedium of criminal law it is the European Union. This is expressed up to now in an unremitting stream of legal instruments touching upon matters of criminal law.

In the Netherlands, proposals were made to punish parents for negligent upbringing when their children commit criminal offences. ${ }^{5}$ Possibly female circumcision will soon also be criminalised if the operation is performed in a foreign country, and girls from high-risk groups should be examined for that regularly. The extension of several

\footnotetext{
${ }^{1}$ Original: Uniestrafrecht. I am indebted to Thom Dieben and Shahram Dana for their work on the English translation.

${ }^{2}$ This does not mean that the European Union cannot be influenced by other entities, such as the United States. See Joachim Vogel, Europäische Kriminalpolitik - europäische Strafrechtsdogmatik, Goltdammer's Archiv für Strafrecht 2002, p.517-534.

${ }^{3}$ P.J. van Koppen, Verankering van rechtspraak, Over de wisselwerking tussen burger, politie, justitie en rechter, inaugural lecture Vrije Universiteit Amsterdam 2003, p.65.

${ }^{4}$ See also J. de Hullu and E.A.M. Verheijen, De beoordeling van Eurostrafrecht, Delikt en Delinkwent 2002, p.696-697.

${ }^{5}$ Letter of the vice-minister for Justice, Niet-vrijblijvende vormen van opvoedingsondersteuning, Parliamentary Documents Second Chamber 1999-2000, 27197, nr.1, p.11.
} 
periods of statutes of limitation feeds the expansion of the omnipotence of criminal law. Criminal law expands continuously: the number of criminal offences, the people involved, the place of the offence and in time. As an instrument criminal law has reached an untouchable status with quite a moral charge. ${ }^{6}$

Recently a new aspect was added to this matter, which eternalizes the status of being a convict and makes it absolute: appeals are made to inform the neighborhood when a sex offender is living in their midst; appeals to take away the Dutch nationality of second generation Dutch or to exclude convicts from employment. Such activities exclude people from society forever. Academics have to set an example towards society to make a stand and to explain that criminal law does not exclude but includes, which means that sometimes things are over and that any convicted person, after he has served his time, returns to society unconditionally, and that there is no place for new sanctions, banishments or pillories. ${ }^{7}$

Within this context it is not surprising that politicians (European and Dutch) try to gain more and more control of the actual enforcement of criminal law. Sometimes by doing so, politicians create a picture that law enforcement is not in good hands (at least not all the time) with those who are responsible for it. By order of the Dutch Parliament (the Tweede Kamer) out of court settlements with certain entrepreneurs were to be submitted to the Minister of Justice for his approval. With the introduction of minimum sentences, judges are forced to impose substantial and high penalties. ${ }^{8}$ Politicians, including members of the Dutch Cabinet, often express a conceited opinion about the way individual criminal cases are dealt with. Their criticism does not address criminal law itself but it turns to various segments of those executing it: the police who do not catch thieves; the Prosecution that does not indict or indicts for offences that are not severe enough; and the court that sentences too low. ${ }^{9}$

Of similar nature are the persistent complaints on European level by the European Commission about not prosecuting EC-fraud. In the opinion of the Commission, prosecution by national authorities is done so badly that it would like to do it itself. The establishment of her own anti-fraud unit was not sufficient for the Commission. For several years, it has been pleading for the foundation of a European prosecutor. All of these are attempts to increase the use of criminal justice. This denies the capabilities of criminal justice and ignores the fact that it is impossible to prosecute every criminal offence. If the capacity of the entire criminal justice system stays the same, automatically the number of crimes without a response increases. As Boutellier says, one could in this respect speak about a permanent feeling of crisis. ${ }^{10}$ Looking at the criminal justice system in this way, things are not going so well.

\footnotetext{
${ }^{6}$ Buruma pointed at the moral character of recent amendments of substantive criminal law. Y. Buruma, Grenzen aan de strafrechtelijke aansprakelijkheid, in: Glijdende schalen, Liber amicorum J.de Hullu, Wolf 2003, p.76.

${ }^{7}$ See also C.H. Brants, Over levende gedachten, inaugural lecture 1999.

${ }^{8}$ But these very same courts also have to interpret rules more and more vaguely described. This leads to more and more room for discretion.

${ }^{9}$ See for an interesting empirical research on the confidence of the public in court decisions: $\mathrm{T}$. van der Meer, Vertrouwen in de rechtspraak, rechtstreeks 1/2004, p.9-55, as well as P.J. van Koppen, who claims that (p.1) criminal law as such meets criticism, however, from his research it appears that the criticism is directed towards several officials in the whole chain of investigation, judiciary and execution of the sentence.

${ }^{10}$ H.Boutellier, De veiligheidsutopie, 2003, 2nd edition, p. 158.
} 


\section{Responsibility of criminal law research}

The latter conclusion is something academics should be concerned about; researchers ought to interfere with the development and shape of criminal law. This is nothing new and it has been happening for years now. What is new is the decreasing influence of criminal law academic community on policy and legislation. How can this decreasing influence of science be explained? In my opinion, the most important reason is the diversity of the working methods of the media and those of scientists. The quick black and white approach of the media, seeking confrontation, does not fit with the nuance and larger correlations of our métier.

Politicians have in some way become increasingly dependent on the media. A politician stating that eradication of all evil is impossible is turned by the media into a politician who does not mind when criminal offences are committed. Which politician has the courage to say that trying to solve a 29-year old murder case goes at the expense of investigating and prosecuting today's criminal offences? ${ }^{11}$

The media often create a wrong image of the reality of law enforcement. ${ }^{12}$ The images of crime and justice created by the media differ so much that this deserves a study of its own. A good example is the unproven notion that the Netherlands has a climate of mild sentence. Our regulations concerning early release are much more severe than those in other countries and convicts serve a greater deal of their imposed sentence. My first impression is that our sentence climate is more severe than that of many other European countries, but proving this demands extensive research. Journalists continue to write that suspects are released due to "technicalities" although these hardly exist anymore since the early nineties. Convicts are released from prison because of "good behavior", a criterion that has not been used in the Dutch criminal justice system anymore for over twenty years. Yet, one keeps reading that those convicted to life imprisonment in the Netherlands are eligible for early release, which is not the case. Life imprisonment is for life.

Fact and fiction are mixed. What is truly going on with crime is not relevant anymore, what matters is image building. ${ }^{13}$ In the way crime is presented, the first matter of importance is that we are dealing with criminals, the notion that in the end the European criminal is a European citizen and that he also emanates from the European society and therefore may claim that freedom, safety and justice is completely lacking. De facto, the pillory has returned from the Middle Ages into our modern society by means of the press. It is therefore justified that courts take into account to what extent suspects have been exposed by the media in their verdicts. In this way, the media contribute to the execution of punishments and thus a real factor. I fear that such a development in which criminal policy is also determined by what happens in

\footnotetext{
11 The experiences with the prosecution of war crimes, years after the facts, learn us that tremendous evidentiary problems may result from the passing of time. At the ICTY such problems have been partly resolved by extensive interpretation of participation in the offence: joint criminal enterprise. Criminal responsibility is implicitly defined as risking to join a group of people later engaging into criminal conduct. See for example ICTY, Judgement, Prosecutor v. Furundžija, Case No. IT-95-17/1-T, T. Ch.II, 10 December 1998, Klip/ Sluiter III-685, par. 216; ICTY, Judgement, Prosecutor v. Tadić, Case No. IT-94-1-A, A.Ch., 15 July 1999, Klip/ Sluiter III-761, par.220.

${ }^{12}$ Brants, p.34-36.

${ }^{13}$ G.J.M. Corstens, Een stille revolutie, Arnhem 1995, p.14.
} 
the media will be strengthened by Europe. In this way fiction can turn into reality. This gaping hole can lead to a race of asking too much, followed by new competencies, followed by a further descent of the actual grip of criminal law on society. In here lies a danger for legal certainty and legal protection. The extension of competencies strengthens the position of the government, but also her scope for policy making and it enlarges the chance of arbitrariness. Indicating this phenomenon is the duty of academics so that a vicious circle can be broken. This can be achieved by discussing criminal law itself as an enforcement instrument.

When crime is presented as a solvable problem there is a risk that means are used that fit such an unreachable aim. In my opinion, criminal law ought to lose much of its inviolability and should be put on a much more modest rank on the scale. This may however not lead to a situation in which complaints about a lack of safety as expressed in society are simply disposed of with classifications like a "healthy sense of justice of the people". Between a fascist rape of justice and a lack of any sense of the needs of society is quite some room. Eventually the criminal justice system exists for the people and it does not operate in a sterile abstract laboratory situation. Criminal justice ought to serve society, but precisely because of that it should be real and trustworthy. ${ }^{14}$ Our social task lies there: inform society about what can and what cannot be done. Keep pointing on facts and consequences and raise the right questions, even if the explanation takes a bit longer. If politicians ask for ready-made solutions that do not exist, they should be answered that this is not possible. ${ }^{15}$ I do not worry about any estrangement between politics and academia; this has always been the situation and it confirms the necessary critical distance. ${ }^{16}$

In another area criminal justice could be under discussion as well. In times when new standards and moral values are being laid down this could eventually lead to the redefining of basic principles of criminal law. This might sound threatening at first but it seems desirable to me since we have gone completely astray in the Netherlands from a principled point of view. Distinctions relevant in earlier times between commission, participation and being an accessory to a criminal offence have in case law degenerated to: you were there, you are in for it! And I have not even started yet about the range of complicity in a criminal organization as referred to in Article 140 of the Dutch Penal Code. This development is at odds with the basic principles of classical criminal law, which expects as its actus reus a "voluntary muscular movement" and only reverts to a controlling instrument when other methods fail. Moreover, the principle of mens rea, in practice, has been abandoned in many fields and strict liability is being introduced into criminal law. ${ }^{17}$

Does this mean that the present criminal law is not up to date anymore? Should we look for new principles and structures? And if we should do so, should we not do that in the Union rather than on national level? Many technical developments have materialized that did not exist in the late nineteenth century when our criminal code was realized. The place of the Netherlands in the world has changed. This was also the conclusion of the Minister of Justice when he opined that we should seek a system

\footnotetext{
14 J. de Hullu, Recidive en straftoemeting, Deventer 2003, p.4.

15 J. de Hullu, Recidive en straftoemeting, Deventer 2003, p.11.

${ }^{16}$ See Parliamentary Documents Second Chamber, 1991-1992, 22268, nr.5, p.5.

${ }^{17}$ See D. Roef, Strafrechtelijke verantwoordelijkheid in de risicomaatschappij, in: P.L. Bal, E. Prakken, G.E. Smaers, Veiligheid of vergelding?, Deventer 2001, p.33-36.
} 
that fits in the present time. ${ }^{18}$ To me that sounds like a correct conclusion. But I still miss the critical and fundamental discussion about new principles. For my part this is more about the question what role we would like give to criminal law in our society and how actus reus and participation are being defined than about detailed questions on whether the criminalisation of sex tourism must be realized also in cases of foreigners integrated as residents into the Netherlands, as now arranged in Article 5a of the Penal Code. For an abstract science like law, nothing is certain for ever and ever; it is all constantly subject to change. This might lead to reconsideration of concepts that had a right to exist for a long time, but this might also lead to the conclusion that some rights cannot be tampered with without abandoning the principles of a democratic constitutional state.

\section{What is the role of the European Union in criminal law?}

It is about time that I introduce to you what I mean by criminal law in the EU; after all you have come here to hear me talk about that. I would like to define criminal law of the EU as the whole of rules of the European Community and the European Union with a dimension of criminal law. This can be distinguished on three levels:

1) a national level:

- the criminal law enforcement of community law (voluntary choice for the use of criminal law/ obligation to enforce) $;{ }^{19}$ as well as enforcement of behavior made liable to punishment by the Union (as incorporated in Council Joint Actions, Framework Decisions and Conventions);

2) a level between nations:

- the regulation of the administrative and criminal co-operation (leads de facto to joint enforcement);

3) a supranational level:

- the real (supranational) European criminal justice system with direct enforcement on the European level. With the exception of enforcement in the field of competition law, this has not been realized elsewhere but there are proposals. $^{20}$

Henceforth in my argument, I will in particular talk about the relation between the national and supranational level, as well as the design of that European criminal justice system.

Thirty-five years ago, on the eve of the completion of the network of treaties on legal assistance of the Council of Europe, offering states the possibility to help each other at every stage of criminal investigation, criminal procedure and execution, Van Agt stated in his inaugural lecture To an extrovert criminal law "that punishment by national authorities is - at the end of the day - not geared towards the preservation of separate national communities, but on the well-being of people in their across the

\footnotetext{
${ }^{18}$ Criminal law in a changing environment (Strafrecht in een veranderende omgeving), Lecture by the Minister of Justice Donner on 1 December 2003 at the Catholic University of Nijmegen.

${ }^{19}$ See J.A.E. Vervaele, Handen en tanden van het gemeenschapsrecht, Inaugural Lecture Utrecht 1994.

${ }^{20}$ On the basis of the case law of the European Court of Human Rights, it is my understanding that EC competition law is to be regarded as criminal law, subject to all requirements of Article 6 ECHR. I thus follow a different approach than Corstens who subdivides European Criminal Law in three parts: 1) cooperation in criminal matters; 2) human rights based in the ECHR; 3) the implementation of community law into national law. See G.J.M. Corstens, Europees strafrecht, in: Rede en Recht, Liber amicorum Nico Keijzer, Deventer 2000, p.11-25.
} 
border society. In this view it is appropriate to entrust the national judge with the enforcement of norms set out somewhere else as well, as long as a more just and more functional dispensation of the fair administration of justice is achieved." ${ }^{21}$ Ten years later, in 1979, the same Van Agt - then Prime Minister of the Netherlands - torpedoed the plan of the French president Giscard d' Estaing for an espace judiciaire with a Dutch veto. ${ }^{22}$ Since then a lot has changed.

First of all, the influence of treaty law on criminal law has risen exponentially. I have calculated how much time it took the Netherlands to conclude fifty treaties with relevance to criminal law in the past century. From April $18^{\text {th }}, 1904$ until August 28 ${ }^{\text {th }}$, 1954 (50 years); until the $8^{\text {th }}$ of August 1975 (21 years); until the $20^{\text {th }}$ of December 1988 (13 years); until the $10^{\text {th }}$ of March 1995 (almost seven years); until the $21^{\text {st }}$ of May 1997 (two years); until the $25^{\text {th }}$ of May 2000 (three years); until September 2003 (3 years and four months). At first it looks as if treaty production is decreasing. This is not the case. Nowadays more and more European legal instruments are adopted in other forms. I started with the donkey work of mapping out all these joint actions, common positions, recommendations, decisions and framework decisions but I still have a long way to go. Not only the European Union, but also other organizations like the United Nations, have contributed to a gradual shifting of the primacy of legislation in criminal law from a national to a supranational level.

It is my assessment that this development will become more intense, especially within Europe. The explanation for this development is to be found in the role of criminal law in society mentioned earlier and the very high pedestal on which the member states have placed it. The Treaty on European Union states in Article 29 that it "shall be the Union's objective to provide citizens with a high level of safety within an area of freedom, security and justice." This ambition can be characterized as the codification of the safety utopia that has been described so poignant by Boutellier. ${ }^{23}$ It links the social feeling to legal possibilities and will in this way determine the position of criminal justice in the European society and the relation between national criminal law and the criminal law of the EU. The treaty also strengthens the citizen's consumer-like claim for safety from the (European) government directly. ${ }^{24}$ Unlike the times of Van Agt and Giscard d'Estaing (in his first political life) national criminal law is under pressure because it turns out to be an ineffective means in the extermination of crime. Sovereignty is in this case seen as being in the way of this effectiveness. $^{25}$ Rather pessimistically it should be expected that politicians will not be able to resist the pressure of transferring more and more criminal law to the European Union. Subsequently, this will increase the pressure on the Union to take

\footnotetext{
${ }^{21}$ A.A.M. van Agt, Naar een extravert strafrecht, Inaugural Lecture, Katholieke Universiteit Nijmegen 1969.

${ }^{22}$ See Supplement to the Parliamentary Documents Second Chamber, 1978-1979, nr.1261. See also A. Weyemberg, L’harmonisation des législations: condition de l'espace pénal européen et révélateur de ses tensions, Bruxelles 2004, p.14-15.

${ }^{23}$ See further H. Boutellier, De veiligheidsutopie, 2nd edition 2003, p.47. This area reappears in identical wording in Articles 41 and III-158 of the Draft Constitution for Europe.

${ }^{24}$ This raises the question whether there is an individual role (duty) for the citizen in creating freedom, security and justice. Also here we see a gradual shift: the Treaty of Amsterdam wanted to bring Europe closer to the citizen. Now, the Draft Constitution for Europe wants to bring the citizen closer to Europe.

${ }^{25}$ See for instance C. Rijken, Trafficking in Persons, diss. Universiteit van Tilburg 2003, p.9.
} 
more enforcement in its own hands. From the Treaty on European Union results thus an increased importance of criminal law to our society. ${ }^{26}$

Is the development criminal law in the right hands with the European Union? The answer to this question is negative at the moment. After all, there are many examples of legislation on Union level without demonstrable necessity (either to legislation, or to European legislation). In 1997, shortly after the apprehension of Dutroux, a Joint Action was promulgated that inter alia addressed the war on international networks of child abuse. In the current criminal procedure nothing of this cross-border component is left. ${ }^{27}$ Following the attacks on September $11^{\text {th }}$, the EU introduced a European Arrest Warrant because, it was argued inter alia, that too many extraditions would be rejected and double criminality would stand in the way of cooperation. Data on large number of rejections have never been produced. There is legislation for problems that do not exist. ${ }^{28}$ The comparative legal research sometimes done by the European Union as a support for a legislative proposal or a proposal to follow implementation of legislation does not meet the requirements that may be set. It gets stuck on a level of normative comparison without involving the context and the actual enforcement. ${ }^{29}$ The scoreboard phenomenon, obliging member states to report when they have ratified and implemented regulations and which authority is responsible for enforcement, brings back memories of the five-years plans of the Soviet-Union. These were always met as well, but disguised reality. The increase in importance of the European Union should in my opinion be accompanied by a realistic insight in European crime. Fijnaut has called for the realisation of a European research area. ${ }^{30}$ If this means the introduction of more European comparative legal research and European criminological research in the preparation, support and review of both legislation and policy this seems to me a good choice. ${ }^{31}$ In this respect a European research and documentation centre on crime is dearly missed. ${ }^{32}$

The Union does regulate enforcement of law, but exclusively in the repressive normative function of criminal law, and not in its power-critical sense. This leads to a lopsided growth at the expense of both the enforcement and the legal protection. In my opinion that is a big problem: Not the European origin of legislation, but the quality and the quantity of European criminal legislation are a constant source of concern. The legislative machinery of the Union makes the criminal law of the

\footnotetext{
${ }^{26}$ The European liberties paradoxically feed the feeling of insecurity. See Ralf Dahrendorf, De Volkskrant 16 April 2004, p.13.

${ }^{27}$ See A. Weyembergh, p. 344: "les grandes difficultés auxquelles sont confrontés les travaux de rapprochement des législations pénales accroissent la tentation de suivre l'événementiel et d'exploiter les drames de l'actualité pour obtenir le consensus nécessaire, ce qui favorise le recours à des définitions larges négociées et adoptées dans l’urgence, sans réflexion approfondie.”

${ }^{28}$ A.H.J. Swart, Een ware Europese rechtsruimte, Inaugural Lecture Amsterdam 2001, p.29.

Additionally, Swart raises the question whether there is no relation with the real willingness of states to make international cooperation successful.

${ }^{29}$ On research methods and comparative criminal law: C.J.C.F. Fijnaut, Rechtsvergelijking en strafrecht(swetenschap): enkele methodologische beschouwingen, Preadvies voor de Nederlandse vereniging van rechtsvergelijking, no.61, Kluwer 2001.

${ }^{30}$ See Fijnaut, preadvies, p.88.

${ }^{31}$ C. Fijnaut, De Europese Unie: een lusthof voor (strafrechtelijke) rechtsvergelijking, Deventer 2001; idem De uitbreiding van de Europese Unie en de strafrechtsvergelijking, in: De meerwaarde van de rechtsvergelijking: Opstellen aangeboden aan prof. mr. H.U. Jessurun d’Oliveira, p.201-213.

${ }^{32}$ Although European Monitory Centers for Drugs and Drugaddiction as well as for Racism and Xenofobia exist.
} 
European Union an ever more complex and inaccessible field of law. The European rule of law would be served by a legislative recess. I have been critical before, without any noticeable success however, that there is no reflection and that the effects of a certain instrument are not even waited for. ${ }^{33}$ A recent example of this pattern I would say is the proposal for a Council Framework Decision on the European Evidence Warrant. In this proposal, EU treaties of 2000 and 2001 are replaced without even coming into effect. Also the earlier mentioned Dutroux-decision has been replaced by a new framework decision of last December. ${ }^{34}$

The activities of the European Union in the field of criminal law show a problembased character. However, it is difficult to recognize any coherence or system. Swift symbolic acting is considered more important then good well thought-out acting. In my opinion, the EU criminal policy is counterproductive, as a consequence enforcement of the law and legal safeguards of the citizen being its victims. A German colleague characterized this as Systemschutz-Strafrecht (criminal law protecting the system): "At the horizon appear a union-wide symbolic criminal law and criminal justice system, as an expression of the incompetence of the political order for a structural reform of society." ${ }^{35}$ What he means is that the use of criminal law for political purposes does lead to a continuation of the political order but does not lead to any realistic use of criminal law. To this I would like to add that this implicates the danger that a paper legal order thus created is in fact unusable in daily practice and that enforcement will take place on a rather arbitrary basis. This can only damage the confidence in the protective function of the rule of law.

\section{How to go ahead? What could belong to the criminal law of the European Union?}

At the occasion of the opening of Eurojust, today exactly one year ago, the Dutch Minister of Justice suggested to create a special European competence for certain cross-border criminal offences and leave the rest of the criminal offences to the national authorities. ${ }^{36}$ To cut a long story short it is his point of view that it is no use to harmonize the entire criminal justice system because $90 \%$ of all criminal offences has only national interfaces. The proposal of the Minister was not worked out in detail yet but it is very interesting. ${ }^{37}$ Especially in the light of the discussion concerning the Constitution for Europe and the upcoming Dutch presidency of the EU, new initiatives may be expected.

\footnotetext{
${ }^{33}$ A.H. Klip, Amsterdams uniestrafrecht, NJB 1998, p.811-816; Neuere Entwicklungen im europäischen strafrecht und in der europäischen Zusammenarbeit in Strafsachen, in: 22. Strafverteidigertag vom 20.-22. März in Erfurt, Schriftenreihe der Strafverteidigervereinigungen, Köln 1999, p.39-54. See also C.J.C.F. Fijnaut, De strafrechtelijke bescherming van de financiële belangen van de Gemeenschap tegen fraude, Delikt en Delinkwent 2000, p.972-988.

${ }^{34}$ Council Framework Decision of 22 December 2003 on combating the sexual exploitation of children and child pornography, OJ 2004, L 13/44.

${ }^{35}$ P.-A. Albrecht, Europäischer Strafrechtsraum: Ein Albtraum?, Zeitschrift für Rechtspolitik 2004, p.1-4.

${ }^{36}$ A few days later this point of view was reiterated in the Memorandum on a European Legal Space, see Een Europese strafrechtelijke ruimte van 9 mei 2003 van de Staatssecretaris voor Europese Zaken, kenmerk DIE-258/03.

${ }^{37}$ See already Ch.J. Enschedé, A Model European Criminal Code?, Report for the Council of Europe 1971, reprinted Arnhem 1990.
} 
A division between European and national criminal law implicates - as I see it - a complete European criminal justice system, a European criminal court, a European Prosecution, European police, all based on European legislation and supervised by a free elected European Parliament. If we do this, it requires a conceptualization of what is to be European criminal law and what it means to be national criminal law. ${ }^{38}$ However the memorandum released by the Minister of Justice in March 2004 does not build on the thought of distinction pronounced last year. ${ }^{39}$ The government holds on to the condition of double criminality in the co-operation with other member states as far as the proscribed conduct has been committed in the Netherlands. Consequently, if the crime is committed and not liable to punishment in the Netherlands, no international cooperation can be provided.

I would like to propose a different model that could look as follows: if the point is that foreign countries can not claim jurisdiction over offences that are not liable to punishment here, yet they are committed here, then the restriction of the jurisdiction ought to be the leading principle. This leads to a completely different rule: jurisdiction inside the European Union is only to be established on a state's own territory. ${ }^{40}$ In this view Germany can no longer prosecute (soft) drug abuse in the Netherlands by a German citizen. But it also means that if the Greek deem it necessary to make the "spotting" of registration numbers of airplanes criminally liable we will assist them with the investigation and prosecution. ${ }^{41}$ This requires a lot of trust, but it offers tremendous advantages for the enforcement of law as well as the protection of the rights of individuals. It is always clear which state can be called upon to enforce. After all the present situation of overlapping jurisdiction leads to a continuous discussion between member states whether an offence should be criminalized and what criminal policy should be followed. ${ }^{42}$ Moreover, abolishing the double criminality requirement and restricting jurisdiction to the territory of the state where the crime was committed builds upon on the existing network of international cooperation in criminal matters. ${ }^{43}$ After all the network of cooperation of the Council of Europe has never been able to incorporate one important theme: an arrangement for jurisdiction conflicts. ${ }^{44}$ The expansion of jurisdiction over the national borders once originated from the solicitude that a suspect might get off scot-free and that it

\footnotetext{
${ }^{38}$ I fully agree with the government's view that a clear delimitation is needed. See Parliamentary Documents Second Chamber, 2003-2004, 28473, nr.35, p.4.

${ }^{39}$ Memorandum on the requirement of double criminality (Notitie Het vereiste van dubbele strafbaarheid in het Nederlandse strafrecht), Parliamentary Documents Second Chamber, 2003-2004, 29451, nr.1; Proposal for a Council Framework Decision on the European Evidence Warrant for obtaining objects, documents and data for use in proceedings in criminal matters COM (2003/0688 final).

${ }^{40}$ It is questionable whether there is a similar need with regard to extraterritorial investigations.

${ }^{41}$ Such an approach corresponds better to the legality principle.

${ }^{42}$ It allows the Netherlands, then, to depart from the defensive and reluctant attitude towards initiatives regarding European Criminal Law. See for instance the government's Memorandum on Criminal Law and Criminal Procedure in Europe (Strafrecht in Europa), Parliamentary Documents Second Chamber, 1998-1999, 26656, nr.1. See also P.H.P.H.M.L. van Kempen, Waarborgen tegen de onwrichtende werking van Eurostrafrecht, Glijdende schalen, de Hullubundel, p.247-266.

${ }^{43}$ A.H.J. Swart, Goede rechtsbedeling en internationale rechtshulp in strafzaken, Inaugural lecture, Deventer 1983.

${ }^{44}$ Various attempts to solve the problem by means of priority rules with regard to jurisdictional principles failed. However, it did lead to an interesting study: Council of Europe, Extraterritorial Jurisdiction. If the European Union would prevent the jurisdictional conflicts, it would finally respond to its obligations under Article 31 sub c Treaty on European Union.
} 
therefore should be possible to call him to account in his own country, but not to correct the criminal policy of another country. In the end there are differing opinions about just a few crimes. Most of the criminal offences have been made liable to punishment in some sort of form in the entire Union. The differences that remain are probably too important to neglect.

The demarcation just presented by me deals with the relation between different member states. It gives no solution for difficult cases in which the locus delicti can not be easily placed in one state ${ }^{45}$ These cases ought to be arranged on Union level. We therefore need to set criteria for the cases that should be dealt with on a European level.

In the memorandum "European criminal law" presented by the Netherlands' government last year, the following was stated: "An effective war on crime against the interests of the Union (forgery of the Euro and fraud against the financial interests of the Community) and of severe cross border crime, that has to be defined but which can vary from smuggling of illegal goods or persons to the harming of the environment, will in the end demand its own homogeneous jurisdiction that is not cut through by national borders." 46

In fact, the Minister appeals to criminological insights with regard to the manifestations of crime and more in particular with regard to the question whether the offences concerned are border crossing. ${ }^{47}$ In my opinion, this is the correct road. I consider the current methodology not very well thought-through: establishing an organisation first: Europol, the European Public Prosecutor, or introducing new criminal offences about topics in the news right before a European summit. After all this only influences the image building, not the real law.

The demarcation ought to be found in substantive criminal law, not in conditions for cooperation. For this reason, criminal offences that are to be part of the European criminal law should meet certain conditions. What are these conditions? In my opinion there are three cumulative conditions:

1. the criminal offence manifests a cross-border character.

2. the prevention, tracing and trying of such an offence experiences more difficulties on national level than on European level.

\footnotetext{
${ }^{45}$ Apart from the problem that there is more than one interpretation of jurisdictional principles. See H.D. Wolswijk, Locus delicti en rechtsmacht, diss. Utrecht 1998.

${ }^{46}$ Memorandum of 9 May 2003.

${ }^{47}$ See already D. van Eck, Het universele karakter van het strafrecht, opstellen over recht en rechtsgeschiedenis, aangeboden aan D. Hermesdorf, Kluwer 1965, p.149-150: "De ontwikkeling naar een internationaal strafrecht, in zoverre dit hetzij bij de inhoudgeving der normen, hetzij bij de handhaving der normen gedeeltelijk de taak van het nationale gezag gaat overnemen, zal een ontwikkeling moeten zijn, die beslist wordt door het criterium, welk organisatorisch verband der samenleving het strafrecht op de meest verantwoorde wijze zal handhaven. Daarbij zal echter rekening mee moeten worden gehouden, dat de uitvoering van het strafrecht slechts één van de vele taken is, die aan het samenlevingsverband der mensen zijn opgedragen. De beslissing omtrent de verdeling van strafrechtelijke competenties mag dus nooit geschieden naar criteria, die louter en alleen betrekking hebben op de uitoefening van het strafrecht. Het belang van een goede handhaving van het strafrecht zal moeten worden gezien in het gehele verband van de taken, waarvoor de menselijke samenleving zich ziet gesteld.”
} 
3. the criminal offence is related to a European field of policy. ${ }^{48}$

The criminal offences involved have a locus delicti in several countries, which makes it difficult to designate one particular state as the most appropriate one. Examples of such offences are to be found in customs and excise law, subsidy fraud, money laundering, trafficking in human beings and drugs and arms trade. The second condition deals with efficiency. If the case involves border crossing aspects but national law enforcement agencies can handle them without problems, there is no need for European involvement. ${ }^{49}$ The third element ensures that various enforcement modalities are seen in coherence, but it also emphasizes the thought for subsidiarity.

Naturally, there will be suspects that will not follow such a division of jurisdiction when they plan to commit a crime. Factual complications will occur in which suspects commit European and national criminal offences. The principle of a fair administration of justice, derived from the transfer of proceedings, can play a decisive role in the search for the most appropriate forum here. ${ }^{50}$

Thus, the European legal area leads to three rather well-defined jurisdictions: national, European and outside the European Union. ${ }^{51}$ I feel less enthusiastic about the plans of the European Commission to establish a European Public Prosecutor as expressed in the Corpus Juris. It creates a hybrid system, that keeps to the middle between national and European enforcement. ${ }^{52}$ The proposed articles III-171 et seq. of the draft constitution of Europe strengthens this hybrid character and they offer no new approach. Similar objections exist against the American solution in which the definition between federal and state criminal law is not very clear and leads to several jurisdictional conflicts. ${ }^{53}$ If we decide to introduce a new European criminal justice system, the European influence on the national criminal justice system will be much less. ${ }^{54}$ Furthermore, it dissolves the objection that national priorities would be crossed out when more hierarchal competences are given to Europol or Eurojust. ${ }^{55}$

It is not all roses in such a perspective. A European system inevitably also has snags attached to it. New organs are created, which leads to a increase of data flows. A

\footnotetext{
${ }^{48}$ See my Conditions for a European Corpus Juris Criminalis, in Michael Faure, Jan Smits and Hildegard Schneider (eds.) Towards a European Ius Commune in Legal Education and Research, Intersentia 2002, p.111. In general, the substantive norm finds its basis in these cases in community law J.A.E. Vervaele, Handen en tanden van het gemeenschapsrecht, Inaugural lecture Utrecht 1994, p.36. ${ }^{49}$ See Parliamentary Documents, First Chamber, 2003-2004, 28350 (R1720) and 28351, B, p.2.

${ }^{50}$ A.H.J. Swart, Goede rechtsbedeling en internationale rechtshulp in strafzaken, Inaugural Lecture, Deventer 1983.

${ }^{51}$ See also the Minister of Justice, Parliamentary Documents First Chamber, 2003-2004, 28350 (R1720) en 28315, B, p.4).

52 The Netherlands' governments explicitly characterised the European Public Prosecutor in this way. See Parliamentary Documents, First Chamber, 2003-2004, 28350 (R1720) and 28351, B, p.2.

${ }^{53}$ In 1971, Enschedé rejected the American Model Penal Code as a suitable example for a European Model Penal Code, see Arnhem 1990.

${ }^{54}$ In several of the Memorandums on European Criminal Law the government enumerated the principles of Dutch law that were non-negotiable. See Memorandum on the relationship between community law and criminal law (Notitie betreffende de verhouding gemeenschapsrecht - strafrecht), Parliamentary Documents Second Chamber, 1991-1992, 22300 VI, nr.39; Memorandum on Criminal Law and Criminal Procedure in a European context (Notitie Strafrecht en strafprocesrecht in Europees verband), Parliamentary Documents Second Chamber, 1998-1999, 26656, nr.1.

${ }^{55}$ The Minister of Justice rightly pointed at this in his 29th April 2003 speech delivered at Eurojust.
} 
system like this also needs to be psychologically accepted by national law enforcement agencies. ${ }^{56}$ A new institute should not be seen as a threat or as a competitor and in this way be deprived of information. The not particularly prosperous position of Europol makes one pessimistic.

\section{What does this state of affairs mean to harmonisation and mutual recognition?}

Harmonisation of national criminal law is not necessary for the system chosen by me in which there is a European criminal justice system for certain offences and a national criminal justice system for the other offences. The present harmonisation of criminal law has been criticized many times and for good reasons. It starts from the impure premise that double criminality stands in the way of cooperation in criminal matters. The chosen method is counter-productive. The real influence of the harmonisation model has so far been marginal, or even absent. ${ }^{57}$ In the first place this has to do with the character of compromise legislation. Instruments are often vaguely written and non-binding. Every member state is left some room how to interpret the instruments. The second reason for the variety of enforcement is the fact that implementation is obligatory. By interpreting the implementation obligations in a "rather national" way in its domestic implementing legislation it is possible for a member state that tasted defeat in the negotiation process to have its own way after all. $^{58}$ The third reason exists in the absence of a common court. The actual role of the Court of Justice in the explanation of Framework Decisions in preliminary rulings is yet to be determined. The fourth reason is the use of different authentic languages. This leads to situations in which there are major differences in the final enforcement in the member states. The day after tomorrow the European Union will grow from 15 to 25 member states, from 375 million citizens to 450 million citizens. That magnitude makes the finding of a common denominator even harder then now. The binding force of harmonisation will decrease even more.

Starting from separate jurisdictions - a European one with regard to specific European offences and several national jurisdictions on behalf of national offences - there is then no need for the condition of double criminality. Accordingly, one reason for harmonisation of substantive criminal law is lost. Although in my assessment harmonisation may fulfil a function with regard to procedural aspects of law. This requires an explanation.

If the member states accept from each other that the execution of jurisdiction is exclusive, this will lead to an important contribution to an unconditional mutual recognition of hand- over warrants of persons and exhibits and other decisions. In a system of unconditional recognition, the barriers between criminal justice systems disappear. ${ }^{59}$ In order to come to a complete freedom of movement, several obstacles have to be removed. For example, the conditions to proceed with the apprehension of

\footnotetext{
${ }^{56}$ See A.H. Klip, Integrated Protection of the Community's Financial Interests: Shift from "StateState"Approach towards Verticalisation of the Procedure?, in: J.A.E. Vervaele (ed.), Transnational Enforcement of the Financial Interests of the European Union, Intersentia 1999, p.95-108.

${ }^{57}$ See for example T. VanderBeken, From Brussels with Love, Bespiegelingen over de invloed van de Europese Unie op het Belgisch strafrecht, Preadvies voor de Vereniging voor de vergelijkende studie van het recht van België en Nederland 2002. See Weyembergh, p.336.

${ }^{58}$ See Weyembergh, p. 342.

${ }^{59}$ A.H.J. Swart, Een ware Europese rechtsruimte, Inaugural Lecture, Deventer 2001, p.24.
} 
suspects differ from one member state to another. This puts a member state under pressure that sets higher conditions. Similar problems can occur by other means of coercion and the collection of evidence. The convergence towards one another of the conditions that are to be fulfilled before search and seizure is allowed will take away the objections against the recognition of a foreign order.

Such findings show the need for a conceptualization of the principle of mutual recognition. What is it exactly that needs to be recognized? That some material conditions need to be met before applying any methods of coercion? That a certain authority has determined this? That the requested country applies the procedural rules for collecting evidence as applied by the requesting state? And why should the obligatory execution of a foreign request interfere with the state's own administration of justice? In short, the notion needs to be provided with a concept.

In the present situation, the state that makes the first move determines that another state ought to acknowledge something. Why in a system of mutual recognition should a state that prosecutes be given priority over a state that has decided to attach no consequences to a certain act? With the limitation of jurisdiction, such a question is no longer under discussion.

\section{What would European criminal justice look like?}

Previously I spoke about the distinction between European and national criminal law, but I have not said anything about the creation of European criminal law. What could it look like?

Basically there are two methods to determine how European criminal law and criminal procedure are to be given shape and content. At this level, we also need to think about the law of criminal procedure because after all it is all about the creation of a new system. The first method is to derive the system from the work already performed by the European Union. The second one is to induct it from common criminal traditions. Both exercises will be anything but easy. This is not surprising. It would only be the third time in history that attempts are being made to create a common criminal justice system in Europe. After the Romano-canonical criminal law and the Napoleon's Code Pénal, the circumstances are now fundamentally different.

What does it mean if we try to deduct the common denominator out of the instruments of law already accepted by the Union? The substantive part of criminal law can be characterized as strict liability. ${ }^{60}$ The real conduct of the offender is not really important. What matters is the position or responsibility of the offender. Perhaps building on the EU economic regulation law of the internal market determines EU views here. The instruments of the European Union contain elements of what belongs to the general part of criminal law in all legal systems. Since there has been no systematic thinking on this at Union level, there are a lot of loose ends. They tell us something about what the Union sees as an offender, and how it sees complicity in an offence as well as what the definition of a criminal offence should look like. Almost without exceptions very general articulated definitions of complicity are being used.

\footnotetext{
${ }^{60}$ A development especially to be found in the case law of international criminal courts.
} 
The required intent is inferred from the manifestation of the behavior (art 1 paragraph 4 EC Fraud Convention). Furthermore, criminal liability of legal persons and the formal and actual executives of those legal persons must be provided for (art 6 Framework decision on combating the sexual exploitation of children and child pornography). If criminal liability can be founded on the competence to represent a legal person, to take decisions on behalf of the legal person, or to supervise a legal person, the meaning of defenses and excuses is strongly reduced. A judgment about the possible applicability of defenses and excuses is already implicit in the mens rea of the offender with these crimes. Apart from that, some criminal policy elements can be detected - particularly from the preambles - that could influence substantive criminal law. The EU norm is striving for the definitive elimination of criminal behavior (or even criminals) and prevention of recidivism.

This method does not bring much insight into the development of criminal procedure. The third-pillar-acquis contains relatively few provisions concerning criminal procedure. That makes sense because so far enforcement is a national affair. The emphasis lies in particular on harmonization and facilitating cooperation.

To determine what could be European criminal law in the first method, I deducted a few things from present EU-law. In the second method, European criminal law is deducted from the common criminal traditions of the member states. ${ }^{61}$ The general part of criminal law (legality, actus reus, mens rea, and participation) and criminal procedural law are of a greater importance than the specific penalizations. ${ }^{62}$ Art 6 of the EU-Treaty offers a legal basis to deduct these from the cultural traditions of member states. Besides that, we have case law of the European Court of Justice about the constitutional and national traditions of member states. General principles of community law have been developed as well. ${ }^{63}$

What does such a first stock-taking of the criminal traditions bring? First of all, the individual rights that play an important role in criminal law. Due to the harmonizing role of the European Convention for the Protection of Human Rights and Fundamental Freedoms, they are more or less the same in the several member states. If we apply the same method on aspects of substantive criminal law and procedure a more varied image arises. ${ }^{64}$

There are quite a lot of differences in the field of legal culture that hamper the search for parallels. More or less uniform regulations can be interpreted rather differently. For example the principle of legality, which means that no conduct is liable to punishment without a preceding legal provision, will lead to different interpretations concerning the standard that may be set for the clarity of the law (lex certa). Legal

\footnotetext{
${ }^{61}$ Such a deduction method may be compared to what harmonisation does.

${ }^{62}$ See for example W. Bottke, Die Struktur von Täterschaft bei aktiver Begehung und Unterlassung als Baustein eines gemeineuropäischen Strafrechtssystems, in: Bausteine des europäischen Strafrechts, Coimbra-Symposium für Claus Roxin, 1995, p.235-246.

${ }^{63}$ See for example Court of Justice, 5 March 1980, Ferwerda, C-256/78, ECR 1980, 623: 13 November 1990, Fedesa, C-331/88, ECR I-4057; 4 October 1991, SPUC, C-159/90, ECR 1991, 4658; 14 May 1974, Nold, C-4/73, ECR 1974, 491; 13 December 1979, Hauer, 44/79, ECR 1979, 3727; 21 September 1989, Hoechst, C-46/87 and C-227/88, ECR 1989, 2859.

${ }^{64}$ Of course there is more criminal procedural law than the ECHR, see M. Delmas-Marty, Procédures pénales d’Europe, Paris 1995.
} 
culture also tells us something about the perception of the law of another legal system. For example, a lot of countries that practice the principle of opportunity in the prosecution of suspects pass criticism on countries with a legality principle because they think that legality leads to rigidity and extreme use of the criminal law. Meanwhile, from the reverse perspective, the opportunity principle is accused of leading to arbitrariness. In reality, both systems have taken off the sharp edges of their system and by doing so overcame the criticism. A recent discussion that took place in the Netherlands concerning minimum penalties is another example of the dangers that can occur when interpreting foreign law. This discussion took place from the Dutch point of view of a rigid execution of imposed penalties (always 2/3 is executed, no less, no more). On the other hand, countries with minimum penalties have formulated all kinds of exceptions on the minimum penalties. France has taken minimum penalties out of its code all together as judges were sentencing for less severe facts because otherwise in their opinion they were forced to impose too severe sentences. ${ }^{65}$

These are just a few examples but they do show that a search for the largest common denominator will lead to an entire new system, in which none of the national systems will recognize itself completely. Concerning the method of development of a new law of criminal procedure the experiences of international criminal courts can be helpful.

Another aspect of the formation of a European criminal justice system that needs discussion is the language. In a common European criminal justice system, it seems inevitable to me that there will be one legal language. The current use of different legal languages leads to different interpretations. Using notions like opzet (intent) and nalaten (omission) automatically leads to a legal Dutch, if you wish a legal Belgian, explanation. Everyone who knows a little bit about comparative law knows that notions like intent and omission are entirely different concepts, that fit into their own context. When enforcement becomes a common European task, there is no place for the differences resulting from the use of different languages. In striving for integration and harmonization, the Union creates a huge barrier by holding on to the fact that all European languages are considered as authentic languages. ${ }^{66}$ The day after tomorrow there will be twenty of them!

By choosing one language room is given for one European legal language to grow. It speaks for itself that the choice is likely to be English. This might lead to a problem because it may be assumed that the more common part of the criminal justice systems of the member states lies in a civil law structure. Experiences in the various international criminal courts show that a complete new system originates, finding its own balance in spite of the fact that specific regulations come from different systems. Therefore it should be possible that the European legal language English extricates itself from the specific national context. As long as this is not the case and the enforcement of law is purely national, Dutch is the legal language in the Netherlands and thus the academic language. This requires that academic writing and teaching in criminal law is done in Dutch, as this speech was originally delivered in Dutch.

\section{Europeanization of the level of legal protection}

\footnotetext{
${ }^{65}$ A.M. van Kalmthout and P.J.P. Tak, Ups en downs van de minimumstraf, Een verkennende studie naar het voorkomen van minimumstraffen in Frankrijk, België, Duitsland, Engeland en Wales, Nijmegen 2003.

${ }^{66}$ See W.C. van Binsbergen, Integratie, Een revolutie? Inaugural Lecture Utrecht 1963, p.12.
} 
In my exposé about the definition of the jurisdiction of the member states and the founding of a European competence in criminal law, I have hardly spoken about the protection of civil rights belonging to this. The European Union often forgets that transnational enforcement creates its own questions of legal protection. The first pertains to situations in which states cooperate in criminal matters. Protection of civil rights is at the moment rather national and segregated. The adaptation of the protection of civil rights to border-crossing cooperation is absolutely necessary. ${ }^{67}$ Already in 1983, Orie described this in his famous essay as the "crack in the system of international cooperation in criminal matters". ${ }^{68}$ In most cases involving cooperation in criminal matters, suspects and other persons involved lack legal remedies in the requesting state as well as in the requested state. This is the case in the requesting state because one can hardly complain there about illegalities that took place in a foreign country under the responsibility of foreign public servants. In the requested state no complaints can be lodged, because the criminal case is not pursued there and international cooperation in criminal matters often takes place at a time when the suspect is not aware that he is subject to a criminal investigation in the first place. The refusal to acknowledge that there is trans-national enforcement encourages the system crack. In this view, it is not an exaggeration to argue that holding on to a strictly national enforcement of criminal law (and fighting against Europeanization of the criminal justice system) is harmful to the legal protection of suspects and other persons involved. The preservation of two systems of legal safeguards limits the actual legal protection. In this respect, one plus one is zero.

The mutual recognition by member states of each others actions needs to contain all aspects of assistance, and exceptions cannot be made in relation to the responsibility of the member states for each others actions on the basis of the European Convention for the Protection of Human Rights and Fundamental Freedoms. The state that uses the services of another member state needs to carry responsibility in case violations of human rights take place. For cooperating states this leads to a situation in which they not only enjoy the advantages of international cooperation but also have to carry the burdens of it. In this way, one can distance oneself from the relative arbitrariness of the current situation. If the complainant finds out in time which states are involved in the investigation directed against him he has to guess to which state he must direct his complaint - the requested or requesting state. The European Court of Human Rights and the European Commission for Human Rights have always rejected a common responsibility. ${ }^{69}$

A case in point is the Sari case. The ECHR declared inadmissible a complaint alleging a violation of the reasonable time, as stipulated in Article 6 ECHR, against Denmark and Turkey. Indeed, the total procedure for the transfer of proceedings and the subsequent trial toke more than ten years, but every state only took responsibility

\footnotetext{
${ }^{67}$ See for the position of the defence in transnational cases: T. Spronken, A place of greater safety, Bespiegelingen over een Europees Statuut voor de strafrechtsadvocaat, Inaugural Lecture Maastricht 2003.

${ }^{68}$ A.M.M. Orie, De verdachte tussen wal en schip of de systeem-breuk in de kleine rechtshulp, in: Bij deze stand van zaken, bundel opstellen aangeboden aan A.L. Melai, Arnhem 1983, p.351-361.

${ }^{69}$ See A.H. Klip, Die EMRK und die internationale Zusammenarbeit in Strafsachen, Universität Halle, (forthcoming) and The Decrease of Protection under Human Rights Treaties in International Criminal Law, 68 Revue Internationale de Droit Pénal 1997, p.291-310.
} 
for half of it, and according to the Court, this was not unreasonable looking at it on an individual basis. $^{70}$ In my opinion, it should not be the responsibility of the complainant to determine the exact responsibilities of states cooperating in human rights violations. What matters is that the joint action of the states involved was unreasonable against him. On the basis of Article 1 (and the preamble) of the European Convention for the Protection of Human Rights and Fundamental Freedoms, it is the common duty of states which joined the treaty to prevent a violation of the treaty. In my opinion, this is some sort of joint liability. Before the proceedings are considered as a whole, as the ECHR requires under the convention, a citizen should be able to use legal remedies in every state involved.

The European Union's enforcement of criminal law by itself in the future must be conditioned on it becoming a party to the European Convention for the Protection of Human Rights and Fundamental Freedoms. This offers legal safeguards in conformity with the traditions of all member states and considerably more protection than the rather strange and limited selection of human rights in criminal matters that was made in the Charter of the fundamental rights of the EU and the Draft constitution for Europe. $^{71}$

\section{Rounding off}

I would like to finish off.

A lot of water will flow through the river Maas before the European Union will start with a more systematic formulation of a criminal justice system. This is related to all sorts of institutional aspects and to the question of political feasibility. The so-called debacle of December 2003, when the Constitution for Europe did not materialize, will only be favorable for legal development. The Union legislator can use some more time to give a certain quality to its legal instruments. What matters is that the system meets the requirements of human rights treaties and that the new system will introduce criminal law that can be enforced. That may result in less criminal law. Only realistic criminal law can play an important role in European and Dutch society.

\footnotetext{
${ }^{70}$ EHRM, 8 November 2001, Sari versus Denmark and Turkey, 21889/93, par.91 and 99.

${ }^{71}$ See also Articles II-47 - 50 of the Draft Constitution for Europe as well as Articles 47-50 of the Charter of Fundamental Rights of the European Union.
} 